\title{
CONDITIONS OF FORMATION OF CHARNOCKITIC MAGMATIC ROCKS FROM THE VÁRZEA ALEGRE MASSIF, ESPÍRITO SANTO, SOUTHEASTERN BRAZIL
}

\author{
J.C. MENDES*, CRISTINA M. WIEDEMANN**** AND IAN MCREATH***
}

\begin{abstract}
RESUMO CONDICÕES DE FORMACÃO DE ROCHAS MAGMÁTICAS CHARNOCKITICAS DO MACICO VÁRZEA ALEGRE ESPÍRITO SANTO, SUDESTE DO BRASIL O maciço intrusivo de Várzea Alegre, porção central do Estado do Espírito Santo, é um exemplo do magmatismo tardi a pós-tectônico relacionado a um arco magmático de idade Neoproterozóica dessa região. E um pluton aproximadamente circular e inversamente zonado, encaixado em orto e paragnaisses de grau metamórfico alto. No centro do pluton ocorrem gabros que são envolvidos sucessivamente por dioritos/quartzo dioritos, monzodioritos e granitos megaporfiríticos, estando todos os litotipos circundados por um anel largo e irregular de rochas charnoquíticas (opdalitos, jotunitos, opx-quartzo dioritos e quartzo mangeritos). Os charnockitóides são constituídos por plagioclásio, alkali feldspato pertítico/mesopertita, ortopiroxênio, biotita, hornblenda, ilmenita, magnetita, pirita, apatita, zircão e rara allanita e hematita. A composição química destas rochas indica um magmatismo cálcio-alcalino de alto K enriquecido em elementos LIL e HFS. O ortopiroxênio ( $\mathrm{Wo}_{1,6-25}, \mathrm{En}_{30,412}$ e Fs57-674)é parcialmente substituído por biotita, anfibólio e minerais opacos. Os anfibólios têm variações pequenas nos teores de $\mathrm{Al}$ e sua composição varia de hornblenda $\mathrm{Mg}$-hastingsítica a hastingsita magnesiana. Biotita, com altos conteúdos de $\mathrm{Ti}$, tem composições próximas ao membro extremo annita. $\mathrm{X}_{\mathrm{Mg}}$ dos ortopiroxênio, anfibólio e biotita são maiores do que aqueles calculados para as rochas hospedeiras. Os feldspatos da matriz e os megacristais apresentam variação composicional semelhante. Os plagioclásios variam de $\mathrm{Ab}_{65} \mathrm{An}_{32}$ a $\mathrm{Ab}_{57} \mathrm{An}_{40}$, com pequenas variações na molécula de Or. Diferentes graus de exsolução do componente albita justificam as variações encontradas nas composições dos feldspatos alcalinos $\left(\mathrm{Or}_{89} \mathrm{Ab}_{11}\right.$ a $\left.\mathrm{Or}_{69} \mathrm{Ab}_{31}\right)$. $\mathrm{O}$ grau de saturação em $\mathrm{Zr}$ e $\mathrm{P}_{2} \mathrm{O}_{5}$ das rochas charnockitóides do maciço de Várzea Alegre indica temperaturas de cristalização em torno de $950^{\circ} \mathrm{C}$. As temperaturas subsolidus, estimadas através dos pares ilmenita-magnetita e plagioclásio-alcali feldspato, são entre $550^{\circ} \mathrm{C}$ e $630^{\circ} \mathrm{C}$, enquanto que os valores estimados para a pressão de cristalização estão entre 6,5 e $7 \mathrm{~kb}$. Os valores calculados para a $f \mathrm{O}_{2}$ são compatíveis com condições fortemente redutoras, o que é confirmado pelas baixas razões $\mathrm{Mg} /(\mathrm{Mg}+\mathrm{Fe})$ das rochas.
\end{abstract}

Palavras-chaves:

ABSTRACT The Várzea Alegre intrusive massif, in the central portion of the Espírito Santo State, is related to the late to post-tectonic Brasíliano magmatic arc in this region. It is an inversely zoned pluton with an almost circular shape, enclosed by ortho and paragneisses metamorphosed to the amphibolite and granulite facies. The pluton has a gabbroic center surrounded by diorites/quartz diorites, monzodiorites and megaporphyritic granites. All these magmatites are involved by a large and irregular ring of charnockitic rocks (opdalites, jotunites, opx-quartz diorites and quartz mangerites). The charnockites are composed of plagioclase, perthitic alkali feldspar/mesoperthite, orthopyroxene, biotite, hornblende, ilmenite, magnetite, pyrite, apatite, zircon, rare allanite and hematite. Chemical composition of these rocks points towards a high-K

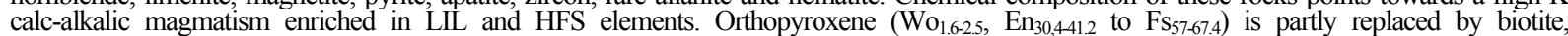
amphibole and opaque minerals. Amphiboles (Mg-hastingsitic hornblende to magnesian hastingsite) show limited variations in the Al-contents. Biotite has compositions close to the annite end member, with high Ti-contents. The Xlig of orthopyroxene, amphibole and biotite are larger than those calculated for host whole rocks. Megacrysts feldspar and from the matrix present similar compositional variation. Plagioclase $\left(\mathrm{Ab}_{65} \mathrm{An}_{32}\right.$ to $\left.\mathrm{Ab}_{57} \mathrm{An}_{40}\right)$ show small variations in the Or molecule. Compositional variations in the alkali feldspar $\left(\left(\mathrm{Or}_{89} \mathrm{Ab}_{11}\right.\right.$ to $\left.\mathrm{Or}_{69} \mathrm{Ab} \mathrm{b}_{31}\right)$ are associated to an unequal exsolution of the $\mathrm{Na}$ component. $\mathrm{Zr}$ and $\mathrm{P}_{2} \mathrm{O}_{5}$ saturation levels of the Várzea Alegre charnockites indicate magmatic crystallization temperature around $950^{\circ} \mathrm{C}$. Subsolidus temperatures, estimated through the ilmenite-magnetite and plagioclase-alkali feldspar pairs, are between $550^{\circ} \mathrm{C}$ and $630^{\circ} \mathrm{C}$. Estimated crystallization pressure ranges from 6.5 to 7 kbar. Calculated fO2 is consistent with highly reducing conditions, which is confirmed by the low $\mathrm{Mg} /(\mathrm{Mg}+\mathrm{Fe})$ ratios of the rocks.

Key-words:

INTRODUCTION The genesis of an anhydrous rock association can be related either to dry metamorphism (granulitic rocks) or to magmatic crystallization, where $\mathrm{Pco} 2$ predominates over $\mathrm{PH}_{2} \mathrm{O}$ Several classical examples of the former, which take place in ancient and large fold belts, have been published: the granulitic rocks from the south of India (Condie et al. 1982, Alien et al. 1985), the Lewisian Complex, Scotland (Drury 1973, Tarney \& Weaver 1987), the Lapland fold belt, Finland (Barbey \& Cuney 1982), etc. In Brazil, granulitic rocks have been studied all over the country and the best known areas are: south of Bahia (Figueiredo 1982, Barbosa 1990), the Juiz de Fora Complex (Campos Neto \& Figueiredo 1990), the granulitic terrains from Santa Catarina (Siga Jr. et al. 1990, Basei et al. 1992) and the Varginha-Guaxupe Complex (Oliveira 1984, lyer et al. 1996).

Igneous charnockitic rocks showing a primary anhydrous paragenesis $\left(\mathrm{aH}_{2} \mathrm{O}<<1\right)$ have also been geologically and geochemically well described. The igneous character is differently preserved among such rocks in several regions of the world, such as the charnockitic gneisses from the south of Norway (Field et al. 1980), the Farsund and Kleivan intrusions, Norway (Petersen 1980), the charnockites from the southeast of Sweden (Hubbard \& Whittley 1979), the mangeritic-charnockitic intrusions from the north of Norway (Ormaasen 1977), the charnockitic gneisses from the north of China (Kaiyi et al. 1985). Examples from Brazil include the charnockites from Ubatuba, São Paulo (Gasparini \& Mantovani 1979), the mangeritic association from São Jose do Rio Pardo, São Paulo (Campos Neto et al. 1988), the norites and charnockitic rocks from the Bela Joana massif, Rio de Janeiro (Rego 1989), the ortho-and clinopyroxene rocks from the Serra do Valentim, Espírito Santo (Fritzer 1991), the charnockiticmangeritic massif from São Pedro de Caldas, Minas Gerais (Janasi 1992), the Caparao Suite, Espirito Santo and Minas Gerais (Seidensticker \& Wiedemann 1993), and the charnockitic rocks from Dom Silverio, Minas Gerais (Evangelista 1996).
Many intrusive bodies containing charnockitic magmatic lithotypes, closely associated with rocks presenting an hydrous primary paragenesis occur in the central portion of the State of Espírito Santo, SE Brazil. The outer ring of the Várzea Alegre massif is a typical example of such well preserved igneous charnockitic rocks.

GEOLOGICAL SETTING Three Brasiliano-cycle metamorphic complexes have been identified in the northern portion of the Ribeira Mobile Belt, State of Espírito Santo. They crop out parallel to the coast line and correspond to three different crustal domains: the Caparao suite, a lower crust segment, formerly included in the Juiz de Fora Complex, the Alegre Complex (partially corresponding to the Paraiba do Sul Complex) and the Costeiro Complex (Sollner et al. 1991). The westernmost crustal segment, close to the Caparao mountain range, comprehends a large belt of infracrustal rocks including granulites and charnockites variably interlayered with metasediments (Seidensticker \&Wiedemann 1993).

The Costeiro Complex is a high-temperature and low-pressure metamorphic belt with cordierite, where a supracrustal series of garnet-biotite and kinzigitic gneisses was partially melted to produce granodiorites and monzodiorites. In a later phase this package was metamorphosed in the presence of a carbonic fluid phase producing either charnoenderbitic or amphibolitic gneisses. Towards the end of the Brasiliano cycle these lithotypes were once more locally migmatized and may be found associated with granites (Sluitner \& WeberDiefenbach 1989). The central belt, the Neoproterozoic Alegre Complex, is bounded by ductile shear zones. It comprises folded supracrustal rocks (biotite gneisses, kinzigites, banded gneisses, migmatites, quartzites, calcsilicate gneisses, and marbles) intruded by orthogneisses with variable compositions.

A general NE-SW to NNW-SSE structural trend shows large scale folding, but also evidence for a contemporaneous stretching parallel to

* UFRJ, Institute de Geociências, Ilha do Fundão, Rio de Janeiro, RJ

** Institute de Geociências, Universidade de Brasília, 70919-970, Brasília, DF

***Institute de Geociências, Universidade de São Paulo, Caixa Postal 11348, São Paulo, 05422-970 
the main fold axes. This is typical for a transpressive tectonic regime (Lammmerer 1987). West directed thrusting of charnockite-nappes was equally reported by Bayer et al. (1986). Widespread melting and intrusion of plutonic masses during the Cambro/Ordovician have been considered as the last stage of the erogenic cycle in this region (Wiedemann et al. 1994). The Várzea Alegre massif, an example of this magmatic event, is enclosed in high-amphibolite to granulite fades para- and orthogneisses of the Alegre Complex.

THE GEOLOGY OF THE VÁRZEA ALEGRE MASSIF The

Várzea Alegre pluton has an almost circular shape, being related to the late to post-tectonic magmatism in this region (Mendes et al. 1997, Wiedemann 1993, Medeiros et al. 1994).

The intrusion is inversely zoned, with gabbros at the eroded center surrounded by diorites/quartzdiorites-monzodiorites and megaporphyritic granites (inner domain, see Fig. 1). A small stock of sphenebearing granite occurs close to the gabbros. The contact between the megaporphyritic granites and the gabbros/diorites is a mixed zone where contrasting lithotypes interfinger with each other. This results in a sort of net veined structures, as well as interesting commingling features and formation of hybrid rocks (quartz diorites and quartz monzodiorites) (Medeiros et al. 1994).

The younger Várzea Alegre intrusion is involved by a large ring of charnockitic rocks: opdalites, jotunites, opx-quartz diorites and quartz mangerites. This outer domain varies in extension from hundred meters, at the $\mathrm{S}$ and $\mathrm{W}$ borders, to almost $4 \mathrm{~km}$, at the $\mathrm{E}$ and $\mathrm{N}$ borders, forming mountain slopes. The charnockitic rocks have dark green color and megaporphyritic texture. Along the contacts to the enclosing rocks the foliation is well marked. Away from this region the rock becomes almost isotropic. When observed, the contacts with the enclosing rocks are sharp and parallel to the igneous foliation. The border foliation and the schistosity of the gneisses are generally dipping towards the center of the pluton. The contacts between the charnockitic outer ring and the magmatites of the inner domain are mainly interfingered, giving rise to locally intense mechanical mixing.

In spite of its homogeneous aspect, the charnockitic rocks show some heterogeneities, such as considerable variation in the amount of megacrysts, sometimes in the same outcrop; presence of dioritic and, to a lesser extent, granitic dikes, as well as feldspar xenocrysts-bearing basic microgranular enclaves; pegmatitic veins causing local fainting of the green feldspar megacrysts; variably assimilated gneissic xenoliths, sometimes originating garnet rich restites.

PETROGRAPHIC AND CHEMICAL FEATURES OF THE CHARNOCKITIC ROCKS The charnockitic rocks consist essentially of plagioclase $\left(\mathrm{An}_{32}\right.$ to $\left.\mathrm{An}_{40}\right)$, perthitic orthoclase/mesoperthite, orthopyroxene (Opx), biotite, amphibole, ilmenite, magnetite, pyrite, apatite, zircon, rare allanite, and hematite. Megacrysts of alkali feldspar and plagioclase, up to $6 \mathrm{~cm}$, as well as quartz, define a porphyritic texture. The matrix is medium to coarse grained and it may be finergrained when compressed against and partially recrystallized around the megacrysts (Figs. 2 and 3). Features of weak ductile deformation are observed in quartz and feldspar grains, as well as curved biotite and twining lamella of plagioclase. The orthopyroxene may be partly replaced by biotite, amphibole and opaque minerals and is altered to chlorite and a brown secondary phase. Primary biotite and amphibole may also occur; variations in the compositions of these minerals could not be detected by electron microprobe. Alkali feldspar replaces plagioclase and the concentration of the perthitic lamella is very variable. Apatite and zircon appear as inclusions, single crystals or associated with mafic minerals. Magnetite replaces ilmenite and predominates over it. Hematite lamellae in ilmenite is relatively rare.

The chemical composition of these rocks indicates $\mathrm{SiO}_{2}$ values ranging from $54 \%$ to $65 \%$. The rocks are enriched in $\mathrm{Ti}, \mathrm{P}, \mathrm{Zr}$, Ba, and $\mathrm{REE}$, relatively rich in $\mathrm{K}$ and $\mathrm{Fe}$, and have low $\mathrm{Mg}, \mathrm{Al}$, and $\mathrm{V}$-contents, when compared to granitoid rocks of similar silica contents (Mendes et al. 1997). A marked compatible behavior has been detected for $\mathrm{Ca}$, $\mathrm{Fe}, \mathrm{Mg}, \mathrm{Ti}, \mathrm{P}, \mathrm{Sr}$ and $\mathrm{V}$, in contrast to the incompatible behavior of $\mathrm{K}$, $\mathrm{Na}, \mathrm{Rb}$, and $\mathrm{Ba}$ (Mendes et al. 1997); very high $\mathrm{Al}, \mathrm{Ca}, \mathrm{Sr}, \mathrm{K}$, and $\mathrm{Ba}$ concentrations in some samples have been pointed by the authors as indicative of possible feldspar accumulation.

Therefore, the Várzea Alegre charnockitic rocks show a met aluminous and high-K calc-alkalic character, with conspicuous enrichment in LIL and HFS elements. These features indicate a mantle contribution associated to crustal melts in the genesis of the rocks. Fractional crystallization and magma mixing were probably the main differentiation process during the evolution of the charnockitic suite (Mendes et al. 1997)

MINERAL CHEMISTRY Orthopyroxene, amphibole, plagioclase, alkali feldspar, biotite, ilmenite and magnetite were analyzed by

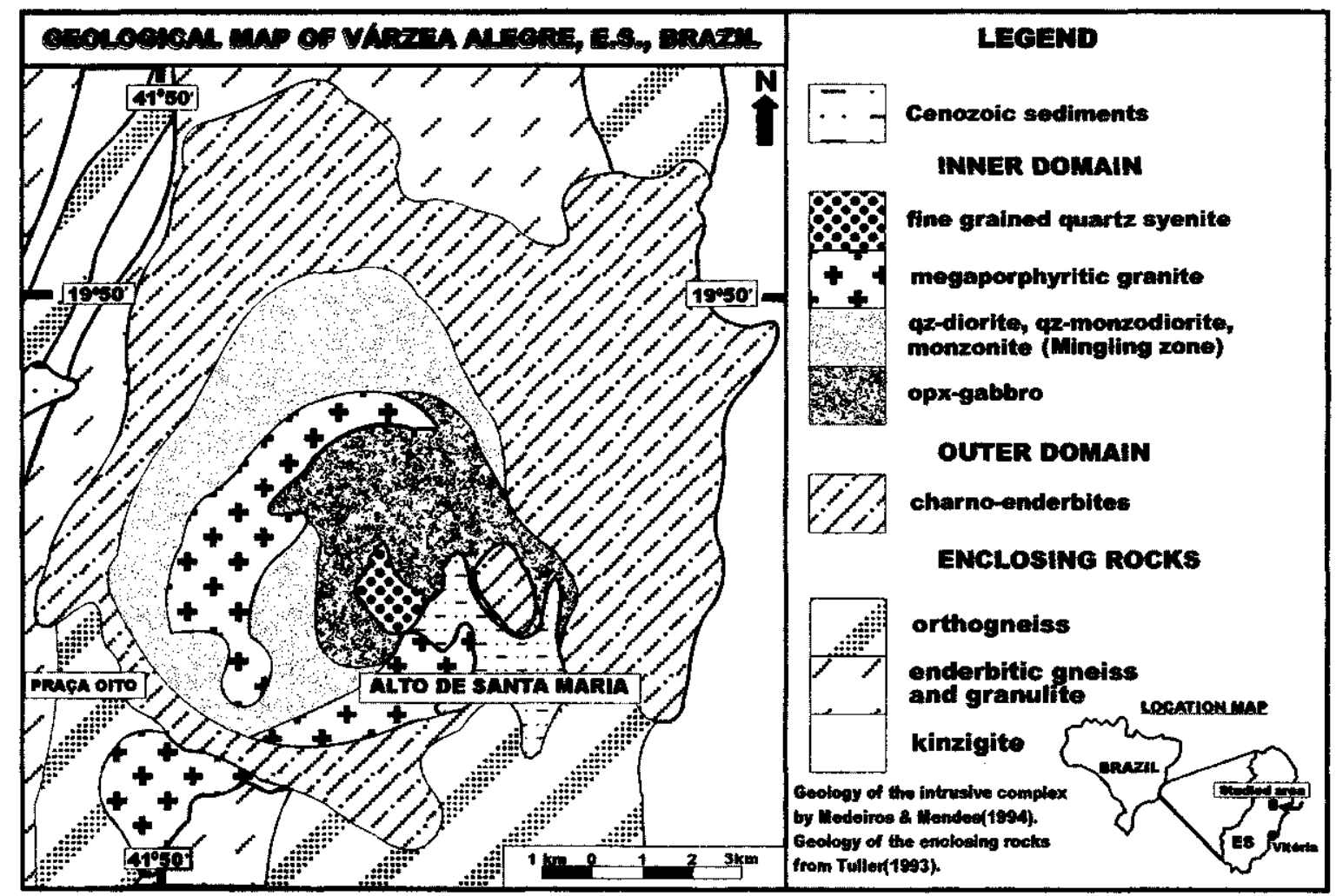

Figure 1 - Geological map of the Várzea Alegra intrusive massif. 


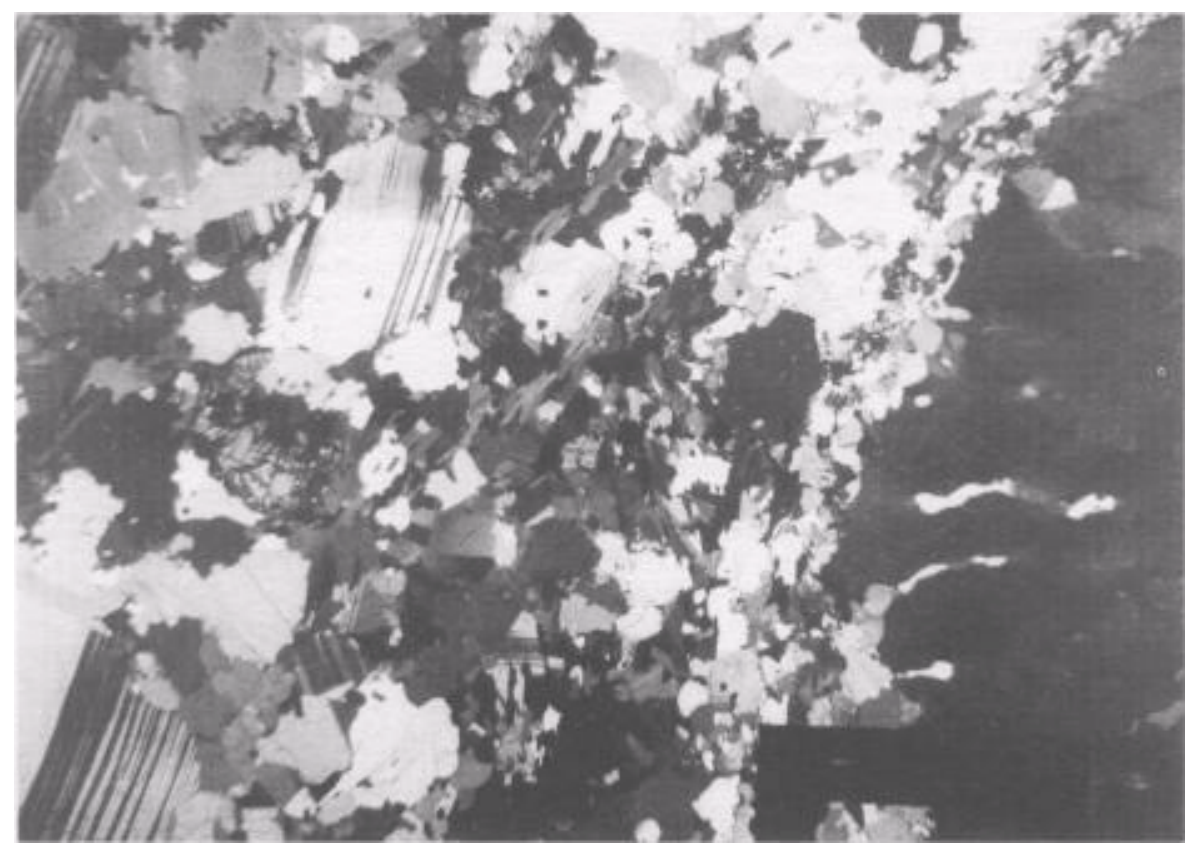

Figure 2 - Photomicrography showing an orthoclase megacrystal (right) and the matrix minerals compressed and partly recrystalized around the megacryst. The inner part of the scale is $10 \mathrm{~mm}$.

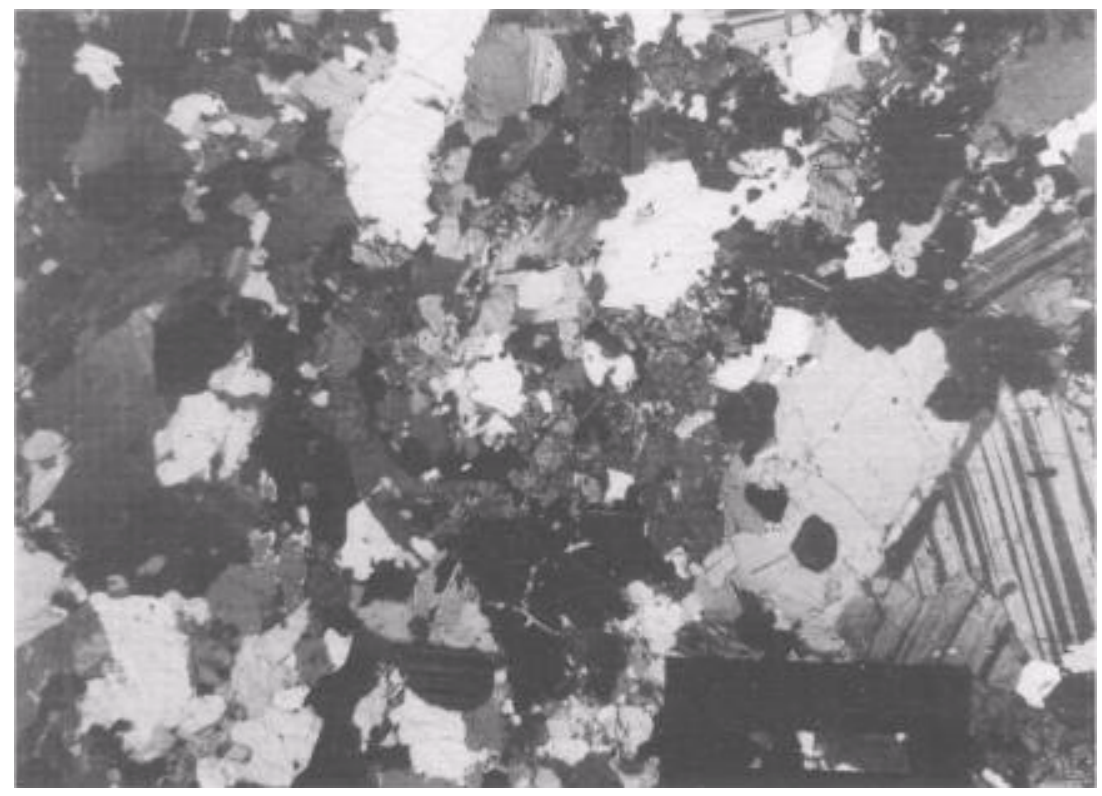

Figure 3 - Photomicrography showing matrix texture in the charnockitic rocks, emphasizing mafic mineral agregate, mainly Opx, at the center of the photo. The inner part of the scale is $1.25 \mathrm{~mm}$.

means of an electron microprobe (JEOL Superprobe JXA-8600) equipped with a Tracer energy dispersive system, at the Institute of Geosciences, University of São Paulo. Operating conditions were $15 \mathrm{keV}$ accelerating potential, $20.1 \mathrm{nA}$ beam current and $1 \mu$ beam diameter. Counting time was 5 or $10 \mathrm{~s}$, depending on the studied phase. The formula units were obtained using the computer program MINPET (Richard 1995).

Orthopyroxene Representative analyses of ortopyroxene (Opx) are shown in Table 1 . The relatively low total values obtained can be explained by the significant degree of alteration of the grains. Despite of this, the compositions show small variation $\left(\mathrm{Wo}_{1.6-2.5} \mathrm{En}_{30.441 .2}\right.$ to $\mathrm{Fs}_{57.674}$ ), with only one sample (VA259) having higher Fe-contents. Most of the elements have restrict variarion in their concentrations. Ca presents the highest ones $(0.55-1.14 \%)$. The observed variations in the Mn-contents must be connected to the Fe-concentrations. The $\mathrm{X}_{\mathrm{Mg}}$ of Opx (around 0.40), as well as amphiboles and biotites, are larger than those calculated for host whole rocks, whose $\mathrm{X}_{\mathrm{Ms}}$, is close to 0.28 . The $\mathrm{Ca}, \mathrm{Mn}$ and $\mathrm{Al}$-contents are not proportional to those found for the whole rocks either.

When compared to the Várzea Alegre rocks, the Opx from the mangeritic and charnockitic rocks from São Pedro de Caldas and Hopen massifs (Janasi 1992, Ormaasen 1977) present lower Fe and $\mathrm{Mn}$ contents and significantly higher amounts of $\mathrm{Mg}$ and $\mathrm{Al}$, with $\mathrm{X}_{\mathrm{Mg}}$ around 0.20. Opx from the gabbros of the inner domain of the Varzea Alegre rocks have higher $\mathrm{Mg}$ contents, and their compositions $\operatorname{areEn}_{46-}$ ${ }_{60}, \mathrm{Fs}_{40-52}$ (Medeiros 1993).

Amphibole The studied rocks have small amounts of amphibole. Their analyses are shown in Table 2 . The formula units were calculated assuming $\mathrm{Fe}^{+3}$ values as the medium point between the maximum and minimum possible values. Figure 4 shows the homogeneous compo- 
sition of the amphiboles, which vary from Mg-hastingsitic hornblendes to magnesian hastingsites, according to Leake's classification (1978). In these amphiboles Si varies from 6.21 to 6.37 atoms per formula unit;

$\mathrm{X}_{\mathrm{Mg}}$ is around 0.38 and the $\mathrm{Al}$ contents show small variations (Fig. 5).

$\mathrm{Ti}$ and the A-site occupancy show a positive correlation with $\mathrm{Al}^{\mathrm{IV}}$ (Figs.

6 and 7). This is common for the hastingsitic compositions, which in turn result from edenite and tschermackite type substitutions (Deer et al. 1966).

The amphiboles of the rocks from the São Pedro de Caldas massif (Janasi 1992) are considerably Fe richer, resulting in $\mathrm{X}_{\mathrm{Mg}}$ varying from 0.08 to 0.3 . The amphiboles of the rocks from the inner domain of the Várzea Alegre rocks have lower $\mathrm{Fe}, \mathrm{Al}$, Ti, and $\mathrm{K}$ contents ,and higher $\mathrm{Mg}$ and $\mathrm{Si}$.

Biotite Table 3 shows very homogeneous chemical composition of the biotites from the Várzea Alegre charnockitic rocks, except for those from sample VA263, which have lower $\mathrm{X}_{\mathrm{Mg}}$. They are compositionally close to annite (Fig. 8). Ti is inversely proportional to $\mathrm{F}$ contents and shows a negative correlation with $\mathrm{Al}^{\mathrm{vi}}$ (Figs. 9 and 10). The concentrations of alkalies tend to be higher with higher Al-contents. Biotites show high Ti contents $(0.63$ to 0.73 atoms per formula unit), which are proportional to their Fe contents. The $\mathrm{Al}^{\mathrm{iv}}$ contents do not correlate with $\mathrm{X}_{\mathrm{Mg} \text {. }}$

Biotites of the rocks from the inner domain have higher $\mathrm{Mg}$ and $\mathrm{Si}$ and lower $\mathrm{Fe}$ contents than thos of the outer domain. They show considerably high Ba contents (Medeiros 1993). Janasi (1992) obtained a large $\mathrm{X}_{\mathrm{Mg}}$ range, from 0.03 to 0.38 , for the biotites from the São Pedro de Caldas region, with a clear predominance of Fe-rich members. They are $\mathrm{Ti}$ and $\mathrm{Cl}$ poorer and $\mathrm{F}$ richer when compared to those from Várzea Alegre.

Feldspars Plagioclase and alkali feldspar show incipient zoning. The irregular distribution of perthitic lamellae may characterize a

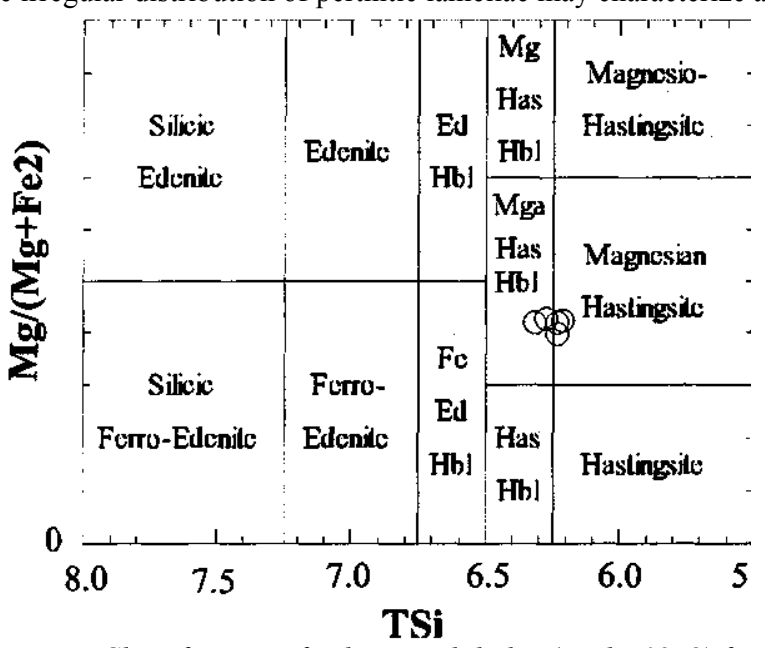

Figure 4 - Classification of calcic amphiboles (Leake 1978) from Várzea Alegre charnockitic rocks.

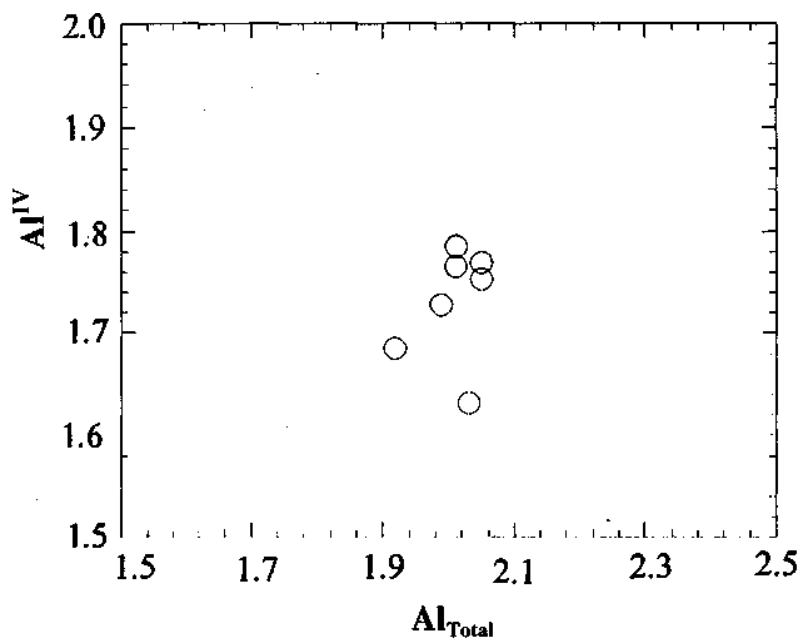

Figure 5 - $A l$ (total) $x A l^{I V}$ diagram for amphiboles from VárzeaAlegre charnockitic rocks. zoned pattern in some grains of alkali feldspar, which in turn may replace plagioclase. The megacrysts and matrix grains present an almost equal compositional variation, as presented in Tables 4 and 5. Plagioclase varies from Ab6sAn32 to AbsvAmo, with small changing on the Or molecule (from 1.1 to $4.3 \%$ ). Ba and $\mathrm{Sr}$ contents are very low, around 0.01 atoms per formula unit. Figs. 1 la and $1 \mathrm{Ib}$ show the compositional variation of megacrysts and matrix plagioclase grains. Compositional variations in alkali feldspar are associated with an unequal exsolution of the Na component. For this reason, the compo-

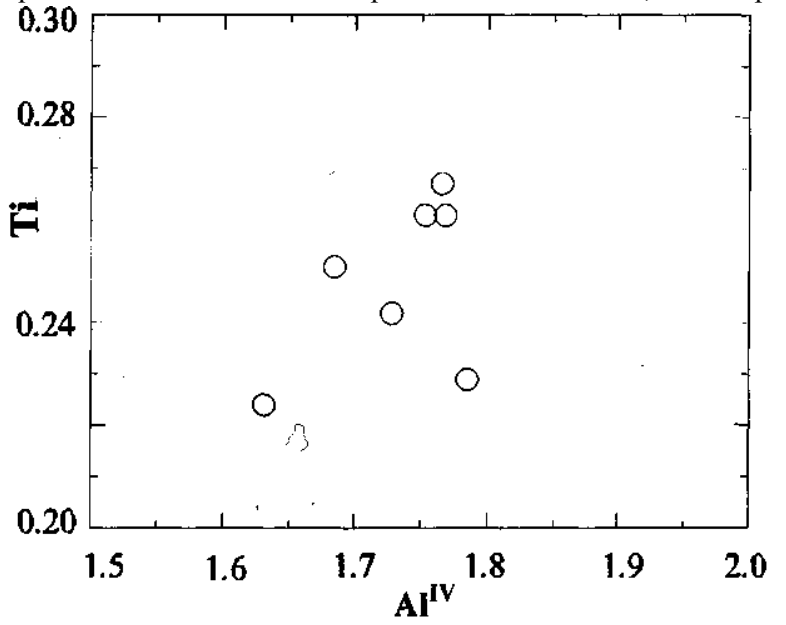

Figure $6-A l^{I V} \quad x$ Ti diagram for amphiboles from Várzea Alegre charnockitic rocks.

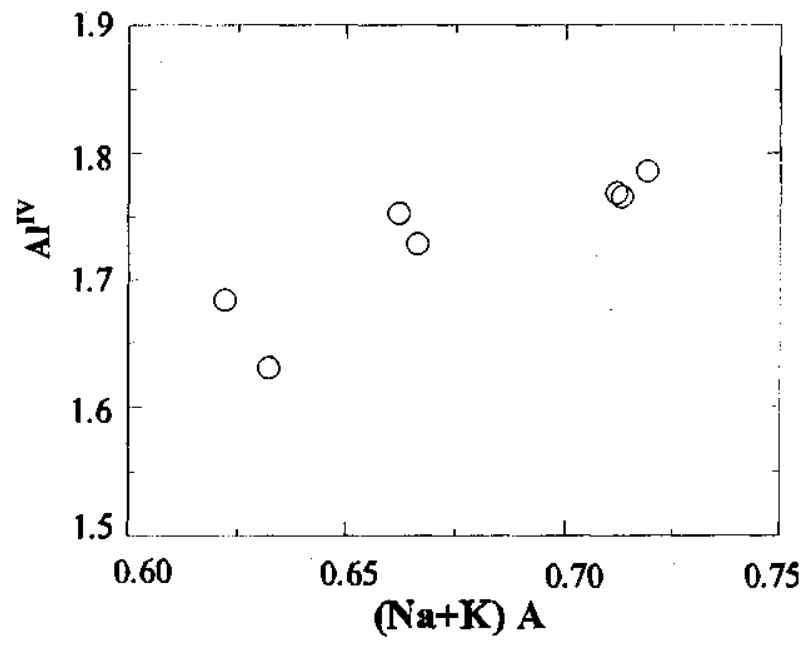

Figure 7 - $(\mathrm{Na}+K) A x A l^{I V} l$ diagramfor amphibolesfrom VárzeaAlegre charnockitic rocks.

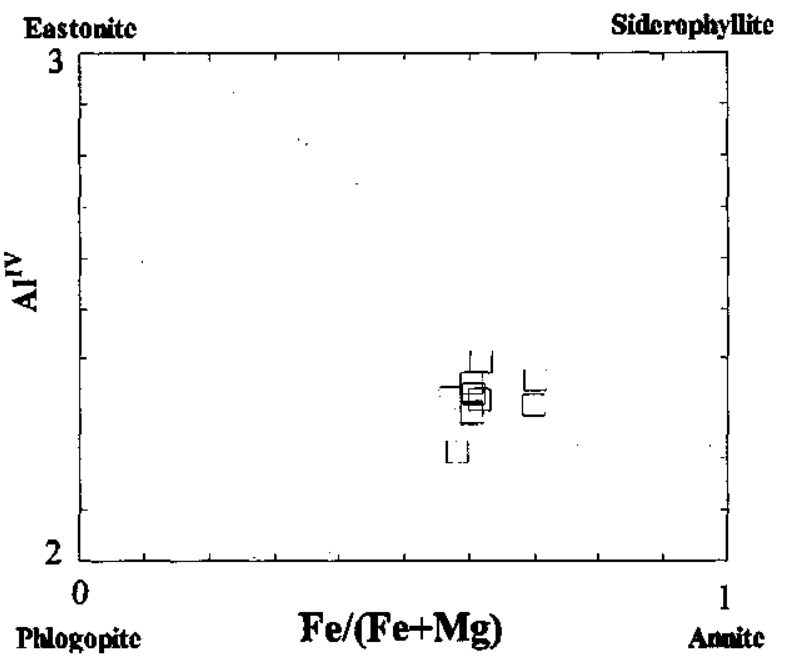

Figure $8-\mathrm{Fe} /(\mathrm{Fe}+\mathrm{Mg}) \times \mathrm{Al} l^{I V}$ diagram for the classification ofbiotites from Várzea Alegre charnockitic rocks. 
Table 1 - Representative analyses of orthopyroxenes from the charnockitic rocks.

\begin{tabular}{|c|c|c|c|c|c|c|c|c|}
\hline Samaple & $\begin{array}{c}\mathrm{VA} \\
261.1\end{array}$ & $\begin{array}{c}\mathrm{VA} \\
261.2\end{array}$ & $\begin{array}{c}\mathrm{VA} \\
182.1\end{array}$ & $\begin{array}{l}\mathrm{VA} \\
182.2\end{array}$ & $\begin{array}{l}\mathrm{VA} \\
252\end{array}$ & $\begin{array}{l}\mathrm{VA} \\
253\end{array}$ & $\begin{array}{l}\mathrm{VA} \\
56\end{array}$ & $\begin{array}{l}\mathrm{VA} \\
257\end{array}$ \\
\hline $\mathrm{SiO2}$ & 49.56 & 49.64 & 49.49 & 49.44 & 48,49 & $48 . \overline{82}$ & 48.70 & 49,46 \\
\hline $\mathrm{TO} 2$ & 0,09 & 0.17 & 0.00 & $0.00)$ & 0.05 & 0.11 & 0.10 & 0.09 \\
\hline $\mathrm{A} 12 \mathrm{O} 3$ & 0.83 & 0.87 & 0.77 & 0.73 & 0.62 & 0.80 & 0.82 & 0.78 \\
\hline $\mathrm{Cr} 2 \mathrm{O} 3$ & 0.02 & 0.02 & 0.01 & 0.02 & 0.00 & 0.00 & 0.08 & 0.02 \\
\hline FeO & 33.64 & 33.12 & 33.58 & 33.58 & 36.33 & 34.23 & 32.84 & 33.20 \\
\hline MnO & 0.80 & 0.99 & 0.87 & 0.85 & 1.33 & 1.07 & 0.88 & 0.85 \\
\hline $\mathrm{MgO}$ & 12.71 & 13.12 & 13.64 & 13.29 & 10.06 & 12.21) & 13.50 & 13.17 \\
\hline NiO & 0.01 & 0.00 & 0.11 & 0.04 & 0.00 & 0.15 & 0.02 & 0.01 \\
\hline $\mathrm{CaO}$ & 1.14 & 1.07 & 0.99 & 1.05 & 0.88 & 0.55 & 0.81 & 0.92 \\
\hline $\mathrm{Na} 2 \mathrm{O}$ & 0.04 & 0.14 & 0.07 & $0 . x)$ & 0.06 & 0.00 & 0.02 & 0.09 \\
\hline $\mathbf{K} 20$ & 0.01 & $0 . x)$ & 0.00 & 0.00 & 0.01 & 0.02 & 0.00 & 0.01 \\
\hline $\mathrm{BaO}$ & 0.11 & 0.10 & 0.00 & 0.00 & 0,07 & 0.60 & 0.10 & 0.00 \\
\hline Total & 98.96 & 99.24 & 99.53 & 99.00 & .97 .90 & 97.95 & 97.87 & 98.60 \\
\hline \multicolumn{9}{|c|}{ Formula Units (Based on 6 oxygens) } \\
\hline TSi & 1.988 & 1.979 & 1.963 & 1.976 & $2 . \overline{(n) 13}$ & 1.987 & 1.966 & 1.989 \\
\hline TAI & 0.012 & 0.021 & 0.036 & (0.).024 & $0,0 \times 0$ & 0.013 & 0.034 & 0.017 \\
\hline MIAI & 0,028 & 0.020 & 0,000 & 0,010 & 0000 & $0,0 \times 0$ & 0.000 & 0.000 \\
\hline MITi & 0,003 & 0.005 & 0.000 & $0,0 \times 0$ & 0.030 & 0.025 & 0.005 & 0.020 \\
\hline MIFE3 & 0,000 & $0,(\mathbf{x}) 1$ & 0,042 & $0,0+3$ & $(0,0) 2$ & 0,003 & 0.0003 & 0,003 \\
\hline MIFe2 & 0.209 & 0.194 & 0.148 & 0.183 & 0,1000 & $a(x)$ & 0,021 & 0.000 \\
\hline MICr & 0,001 & 0.001 & 0.000 & 0.001 & 0.349 & 0.227 & 0.155 & 0.189 \\
\hline $\mathrm{MIM}_{\mathrm{g}}$ & 0.760 & 0.780 & 0.807 & 0.792 & 0.000 & $0.0 \times(x)$ & 0.003 & a.onin \\
\hline MINi & 0.000 & 0,000 & 0.004 & 0,001 & 0,619 & 0.740 & 0.813 & 0.787 \\
\hline M2Mg & 0.000 & 0.000 & $0.00 \mathrm{t}$ & 0.000 & 0,000 & 0.003 & 0.001 & $0,0(0)$ \\
\hline M2Fe 2 & 0.920 & 0.910 & 0.923 & 0.926 & 0,906 & 0,938 & 0,933 & 0.924 \\
\hline M2Mn & 0.027 & 0.033 & 0.029 & 0,029 & 0.047 & 0.037 & 0.030 & 0.029 \\
\hline $\mathrm{M} 2 \mathrm{Ca}$ & 0.049 & 0.046 & 0.042 & 0,045 & 0.039 & 0.024 & 0,035 & 0.040 \\
\hline $\mathrm{M} 2 \mathrm{Na}$ & 0.003 & 0.011 & 0.005 & 0,000 & 0.005 & 0.000 & $(0,0) 2$ & 0.07 \\
\hline $\mathbf{M} 2 \mathrm{~K}$ & (B.0)1 & 0.000 & 0.000 & 0.000 & 0.001 & $0(0.0) 1$ & $(0,000)$ & 0.001 \\
\hline Sumcat & 3.949 & 4.000 & 4.000 & 4000 & 3,999 & 3.999 & 4000 & 3.499 \\
\hline wo & 2,490 & 2.330 & 2.110 & 2.260 & 1.990 & 1.220 & 1.770 & 2.010 \\
\hline EN & 38.68 & 39.72 & 40,49 & 39.43 & 31.61 & 37.65 & 4691 & 39.98 \\
\hline $\mathrm{FS}$ & 58.82 & 57.45 & 57.40 & 57.91 & 66.40 & 61.13 & 57.33 & 58.01 \\
\hline & 0.598 & 0.586 & 0.580 & 0.586 & 0.670 & 0.611 & 0.577 & 0.586 \\
\hline $\mathrm{MgMg}+\mathrm{Fe}$ & 0.402 & 0.414 & 0.420 & 0.414 & 0.330 & 0.389 & (2),423 & 0.414 \\
\hline
\end{tabular}

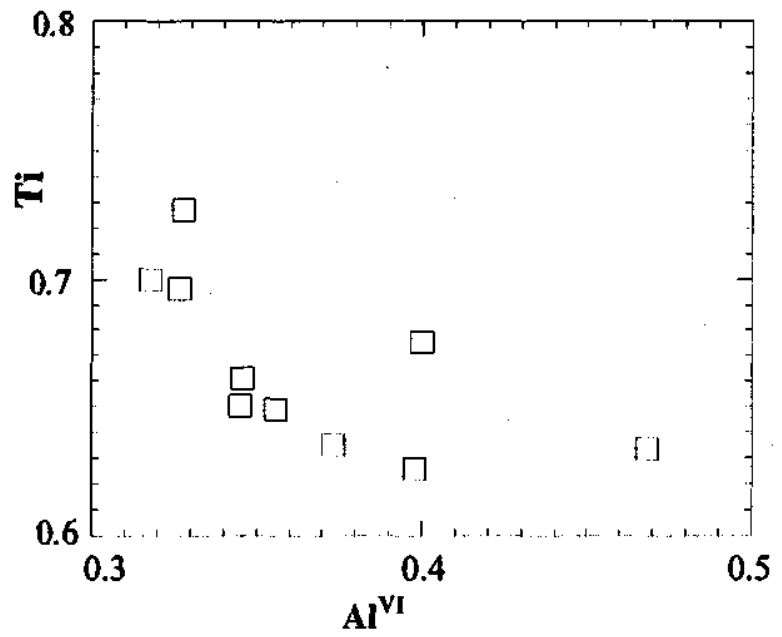

Figure 9-Al ${ }^{V I} x$ Ti diagram for biotitesfrom Várzea Alegre charnockitic rocks.

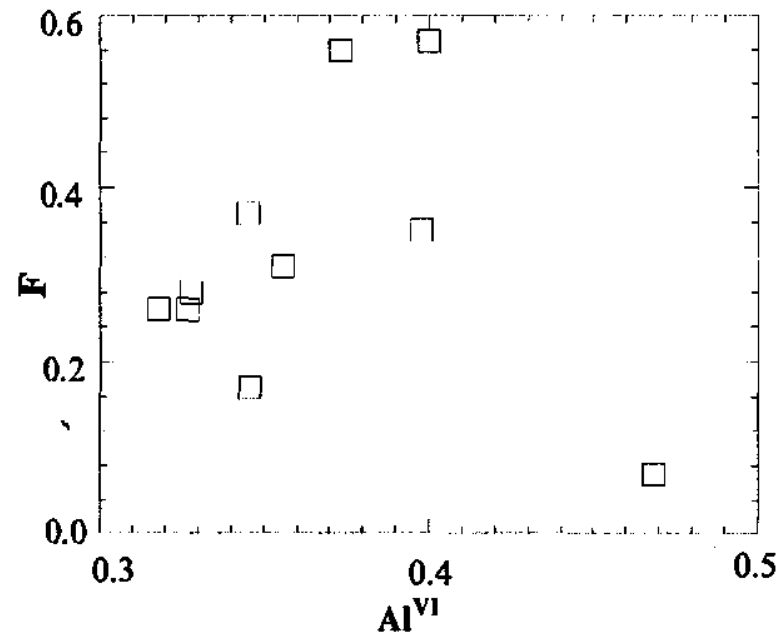

Figure $10-A l^{I V *} \times F$ diagram for biotitesfrom Várzea Alegre charnockitic rocks.
Table 2 - Representative analyses of amphiboles from the charnockitic rocks.

\begin{tabular}{|c|c|c|c|c|c|c|}
\hline Sample & $\begin{array}{r}\mathrm{VA} \\
257.1 \\
\end{array}$ & $\begin{array}{r}\mathrm{VA} \\
257.2 \\
\end{array}$ & $\begin{array}{r}V A \\
182.1 \\
\end{array}$ & $\begin{array}{r}V A \\
182,2 \\
\end{array}$ & $\begin{array}{r}\text { VA } \\
261,1 \\
\end{array}$ & $\begin{array}{r}V A \\
261.2 \\
\end{array}$ \\
\hline $\mathrm{SiO} 2$ & 40.87 & 40.45 & 41.77 & 41.25 & 40.02 & 40,54 \\
\hline $\mathrm{nOO2}$ & 2.10 & 1.98 & 1.95 & 2.18 & 2.22 & 2.26 \\
\hline $\mathrm{Al} 2 \mathrm{O} 3$ & 11.02 & 11.13 & 11.30 & 10.62 & 11.13 & 11.30 \\
\hline $\mathrm{Cr}_{203}$ & 0.03 & 0.06 & 0,00 & 0.02 & 0,00 & 0,04 \\
\hline $\mathrm{FeO}$ & 21.36 & 21.88 & 21.57 & 21.93 & 21.11 & 21.84 \\
\hline $\mathrm{MnO}$ & 0.29 & 0.15 & 0.26 & 0.15 & 0.28 & 0.24 \\
\hline $\mathrm{MgO}$ & 7.73 & 7.62 & 7.22 & 7.63 & 7.14 & 7.24 \\
\hline $\mathrm{CaO}$ & 11.41 & 11.60 & 11.61 & 11.49 & 11.86 & 11.60 \\
\hline $\mathrm{Na2O}$ & 1.33 & 1.47 & 1.18 & 1.27 & 1.11 & 1.37 \\
\hline $\mathrm{K} 2 \mathrm{O}$ & 1.72 & 1.68 & 1.74 & 1.57 & 1.68 & 1.79 \\
\hline $\mathbf{F}$ & 0.16 & 0.16 & 0.20 & 0.24 & 0.30 & 0.18 \\
\hline $\mathrm{Cl}$ & 0.11 & 0.13 & 0.14 & 0.07 & 0.08 & 0.10 \\
\hline Total & 98.13 & 98.31 & 98.94 & 98.42 & 96.93 & 98.50 \\
\hline $\mathrm{O}_{-} \mathrm{F} \_\mathrm{Cl}$ & 0.090 & 0.100 & 0.120 & 0.120 & $0.14 \theta$ & 0.100 \\
\hline$O_{-} F$ & 0.070 & 0.070 & 0.080 & 0.100 & 0.130 & 0.080 \\
\hline O_Cl & 0.020 & 0.030 & 0.030 & 0.020 & 0.020 & 0.020 \\
\hline \multicolumn{7}{|c|}{ Formula Units (Based on 23 oxygens) } \\
\hline TSi & 6.272 & 6.215 & 6.369 & 6.316 & 6.247 & 6.232 \\
\hline TAl & 1.728 & 1.785 & 1.631 & 1.684 & 1.753 & 1.768 \\
\hline SumT & 8.000 & 8.000 & 8.000 & 8.000 & 8.000 & 8.000 \\
\hline CAl & 0.264 & 0.229 & 0.399 & 0.231 & 0.293 & 0.277 \\
\hline $\mathrm{CCr}$ & 0.004 & 0.007 & 0.000 & 0.002 & 0.000 & 0.005 \\
\hline $\mathrm{CFe} 3$ & 0.375 & 0.420 & 0.207 & 0.388 & 0.286 & 0.299 \\
\hline CTi & 0.242 & 0.229 & 0.224 & $0.25 !$ & 0.261 & 0.261 \\
\hline $\mathrm{CMg}$ & 1.769 & 1.745 & 1.641 & 1.742 & 1.661 & 1.659 \\
\hline $\mathrm{CFe}_{2}$ & 2.328 & 2.360 & 2.512 & 2.377 & 2.470 & 2.482 \\
\hline CMn & 0.019 & 0.010 & 0.017 & 0.010 & 0.029 & 0.016 \\
\hline SumC & 5.000 & 5.000 & 5.000 & 5.000 & 5.000 & 5.000 \\
\hline BFe2 & 0.039 & 0.032 & 0.031 & 0.044 & 0.000 & 0.026 \\
\hline BMn & 0.019 & 0.010 & 0.017 & 0.010 & 0.008 & 0.016 \\
\hline $\mathrm{CaB}$ & 1.876 & 1.910 & 1.897 & 1.855 & 1.983 & 1.911 \\
\hline $\mathrm{NaB}$ & 0.066 & 0.048 & 0.055 & 0.061 & 0.009 & 0.048 \\
\hline SumB & 2.000 & 2.000 & 2.000 & 2.000 & 2.000 & 2.000 \\
\hline ANa & 0.330 & 0.390 & 0.294 & 0.316 & 0.327 & 0.361 \\
\hline AK & 0.337 & 0.329 & 0.338 & 0.307 & 0.335 & 0.351 \\
\hline SumA & 0.666 & 0.719 & 0.632 & 0.622 & 0.662 & 0.712 \\
\hline $\mathrm{CCl}$ & 0.029 & 0.0 .34 & 0.036 & 0.018 & 0.021 & 0.026 \\
\hline CF & 0.078 & 0.078 & 0.096 & 0.116 & 0.148 & 0.088 \\
\hline $\mathrm{Fe} /(\mathrm{Fe}+\mathrm{Mg})$ & 0.608 & 0.617 & 0.626 & 0.617 & 0.624 & 0.628 \\
\hline $\mathrm{Mg} /(\mathrm{Mg}+\mathrm{Fe})$ & 0.392 & 0.383 & 0.374 & 0.383 & 0.376 & 0.372 \\
\hline
\end{tabular}

sition varies from $\mathrm{Or}_{89} \mathrm{Ab}_{11}$ to $\mathrm{Or}_{69} \mathrm{Ab}_{31}$ Only two samples show significant variation. The compositional range measured is displayed in Figs. 12a and 12b. Ba contents are high, reaching $4.2 \%$ of the celsian component ( 0.17 atoms per formula unit) and show an inverse relation to Na.

Opaque Minerals Ilmenite presenting discrete exsolution lamellae of hematite, magnetite locally intergrown or replacing ilmenite and pyrite were the opaque phases observed in the charnockitic rocks from the Várzea Alegre region. Table 6 displays representative analyses of ilmenite and magnetite. Ilmenite corresponds to solid solutions where the proportion of $\mathrm{FeTiO}_{3}$ molecules is large, from $84 \%$ to $90 \%$. The low proportion of exsolved $\mathrm{Fe}_{2} \mathrm{O}_{3}$ molecule (up to $12.8 \%$ ) is a clear indication of reducing environment during crystallization. $\mathrm{Mg}$ contents are low, up to $0.66 \% \mathrm{MgO}$ and $\mathrm{Mn}$ amounts are variable, ranging from $0.48 \%$ to $1.59 \% \mathrm{MnO}$.

Magnetites comprise almost pure Fe phases, Mn free, showing $\mathrm{Fe}_{3} \mathrm{O}_{4}$ molecule varying from $95.8 \%$ to $98.7 \%$. They have up to $1.05 \%$ $\mathrm{Al}_{2} \mathrm{O}_{3}$ molecule, what indicates up to $2.6 \%$ exsolved hercinite. The higher calculated percentage for the exsolved ulvospinel was 1.1\%.

PETROGENETIC REMARKS AND CONCLUSIONS An anhydrous magma, with low water activity $\left(\mathrm{PcO}_{2}>>\mathrm{PH}_{2} \mathrm{O}\right)$, was certainly the precursor of the charnockitic rocks from the Várzea Alegre massif. Some authors argue that small amounts of $\mathrm{H}_{2} \mathrm{O}$ in the initial composition of a magma could be sufficient to stabilize hydrous minerals, especially phlogopite-biotite (Wendlandt 1981, Martignole 1979, Hewitt \& Wones 1984, Naney 1983). The presence of individual biotite crystals suggest it is a primary phase, and the rather high $\mathrm{K}_{2} \mathrm{O}$ contents of the less evolved rocks (up to 2.2\%; Mendes et al. 1997), coudl be ascribed to the biotite. On the other hand, amphiboles show textural evidence for late crystallization. In general, the amphibole shows lower $\mathrm{X}_{\mathrm{Mg}}$ than the coexisting biotites (around 0.38) and the $\mathrm{K}_{\mathrm{Ds}} \mathrm{Fe}-\mathrm{Mg}$ for biotites and amphiboles range from 0.89 to 0.97 , pointing towards chemical equilibrium among them (Saxena 1968, Mason 1985). 


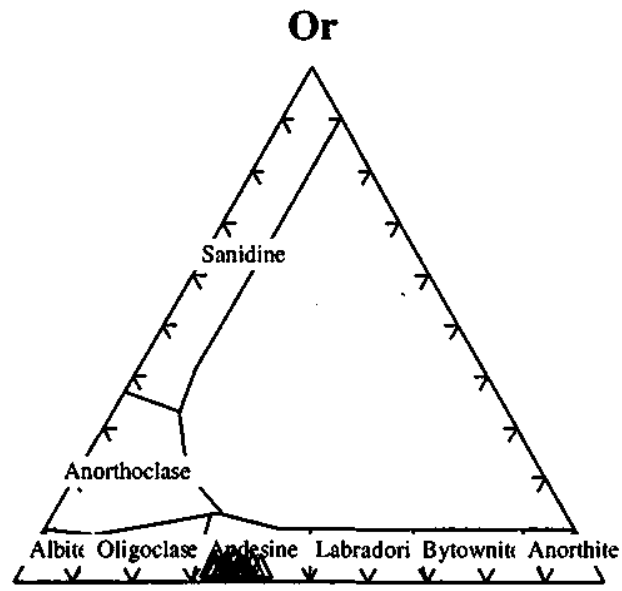

Ab
An

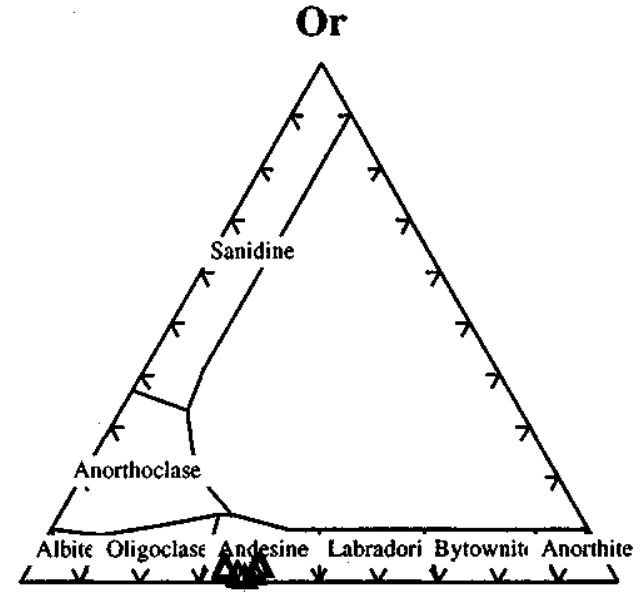

Ab

Figure 11 - Or-Ab-An diagram showing the compositional variation of the megacrysts (a) and matrix (b) plagioclase from Várzea Alegre charnockitic rocks.

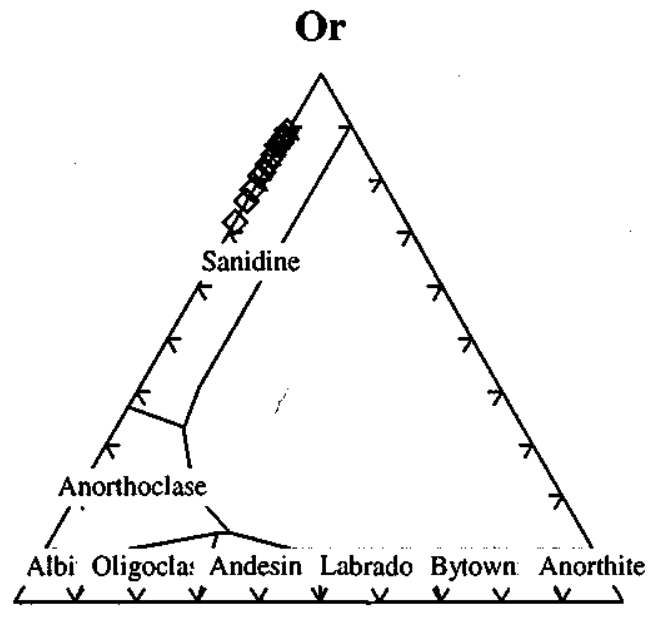

$\mathbf{A b}$

An

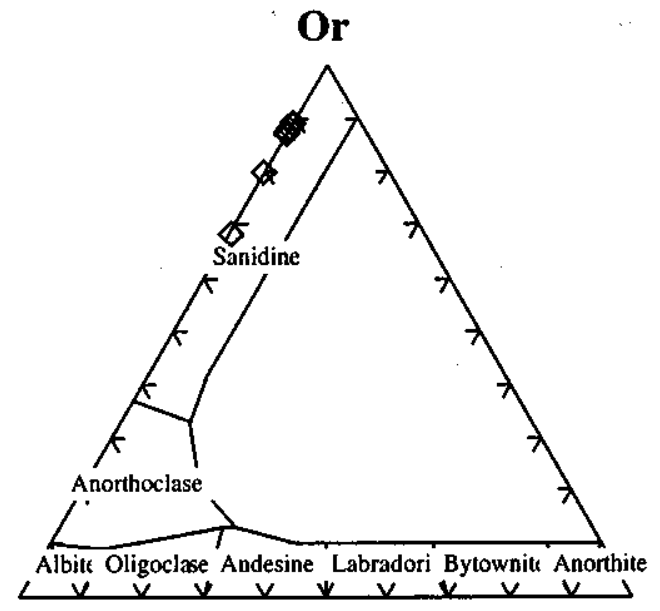

Ab

Figure 12 - Or-Ab-An diagram showing the compositional variation of the megacrysts (a) and matrix (b) alkali feldspar, respectively, from Várzea Alegre charnockitic rocks.

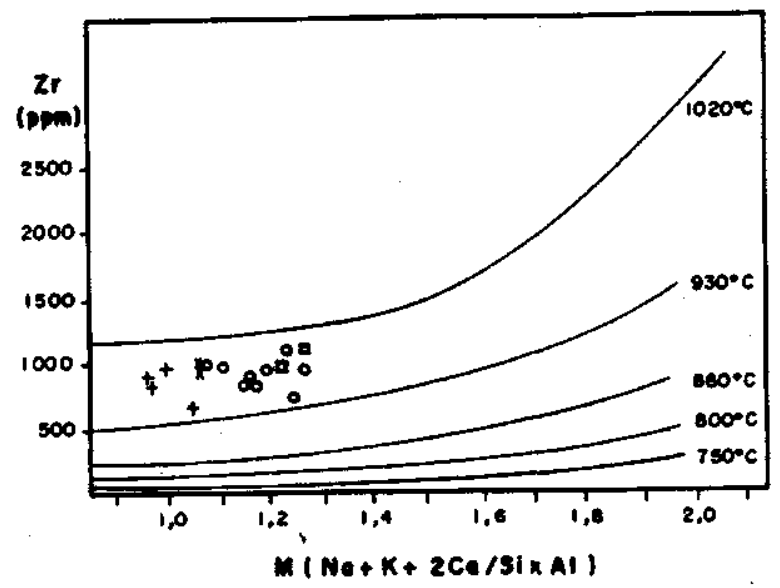

Figure 13-M(Na+K+2Ca/Six Al) versus Zr diagram. The curves are from Watson \& Harrison (1983). Symbols: Opx-Quartz diorites; 0 Jotunites; + Opdalites.

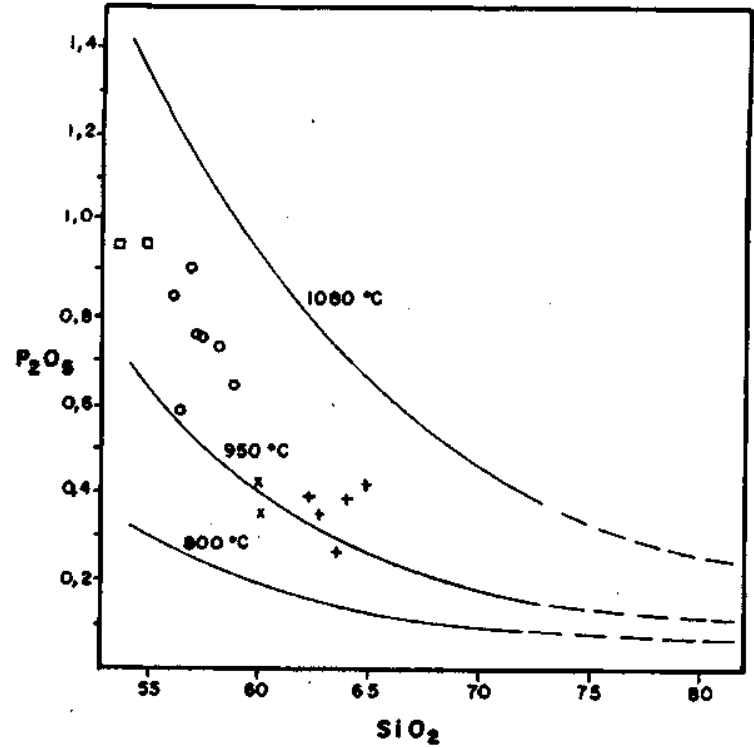

Figure $14-\mathrm{SiO}_{2} \times \mathrm{P}_{2} \mathrm{O}_{5}$ diagram. The curves are from Watson \& Harrison (1983). Symbols: Opx-Quartz diorites; O Jotunites; + Opdalites. 
$\mathrm{Zr}$ - and $\mathrm{P}_{2} \mathrm{O}_{5^{-}}$saturation levels for the Várzea Alegre massif indicate temperature between $950^{\circ}$ and $1000^{\circ} \mathrm{C}$, using the calibration curves of Watson \& Harrison (1983,1984; Figs. 13 and 14). These are the minimum liquidus temperatures of the magma to hold in solution the high concentrations found for these elements. Possible inconsistencies for this geotermometer, leading to false temperatures, could be ascribed to the presence of a cumulate phase (feldspars?) and to inherited zircons. The hypothesis of cumulate feldspars, at low amount, was considered by Mendes et al. (1997).

Table 3 - Representative analyses of biotites from the charnockltic rocks.

\begin{tabular}{|c|c|c|c|c|c|c|c|c|}
\hline Sample & $\begin{array}{r}V / A \\
257.1 \\
\end{array}$ & $\begin{array}{r}\mathrm{VAA} \\
257.2 \\
\end{array}$ & $\begin{array}{r}\text { VA } \\
263.1 \\
\end{array}$ & $\begin{array}{r}\mathrm{VA} \\
263.2 \\
\end{array}$ & $\begin{array}{r}v \vec{A} \\
18: 2,1 \\
\end{array}$ & $\begin{array}{r}\mathrm{VA} \\
182.2 \\
\end{array}$ & $\begin{array}{r}\mathrm{VA} \\
261.1 \\
\end{array}$ & $\begin{array}{r}\mathrm{VA} \\
2 \times 1,2 \\
\end{array}$ \\
\hline $\mathrm{SiO} 2$ & 35.39 & 35.32 & 34,04 & 35,05 & 34,91 & 35.47 & 35.21 & 34.23 \\
\hline TO2 & 5.39 & 5.55 & 5.02 & 5.19 & 5.70 & 5.46 & 5.99 & 5.27 \\
\hline Al2O3 & 14.13 & 14.15 & 14.11 & 14.52 & 13.89 & 13,92 & 13.93 & 14,26 \\
\hline $\mathrm{Cr} 2 \mathrm{O}$ & 0.00 & 0.03 & 0.09 & $0.0 \mathrm{KI}$ & 0.06 & 0.1.04 & $0 .(k)$ & 0.04 \\
\hline$F+O$ & 22.76 & 23.19 & 26.52 & 26,63 & 23,48 & 23.65 & 23.78 & 24.06 \\
\hline MnO & $0.1 \%$ & 0.11 & 0.14 & 0.12 & 0.09 & 0.14 & (1).10 & 0.01 \\
\hline $\mathrm{MgO}$ & 9.65 & 8.54 & 6.34 & 6.45 & 8.52 & 8.76 & 8.33 & 8.34 \\
\hline $\mathrm{Na} 2 \mathrm{O}$ & 0.03 & 0.065 & 0.20 & 0.04 & 0.14 & 0.15 & 0.00 & 0.16 \\
\hline$K 20$ & प.4.) & 4.44 & 4.59 & 9.47 & 9.46 & 8.40 & 9.54 & 9.52 \\
\hline $\mathrm{F}$ & 0.37 & 0,57 & 0.35 & 0,07 & 0.26 & 0.17 & 10.28 & 0.31 \\
\hline $\mathrm{Cl}$ & 0.16 & (1).14 & 0.12 & 0.01 & 0.10 & 0.14 & 0.12 & 0.15 \\
\hline Troal & 97.38 & 97.10 & 96.52 & 97.55 & 96.61 & 97.30 & 97.28 & 96.35 \\
\hline OF_Cl & 0.19 & 0.27 & 0.17 & 0,03 & 0.13 & 0.19 & 0.14 & 0.16 \\
\hline
\end{tabular}

Formula Units (Based on 22 oxygens)

\begin{tabular}{|c|c|c|c|c|c|c|c|c|}
\hline $\mathrm{Si}$ & 5.676 & 5.707 & $5.6 \overline{43}$ & 5.691 & 5.676 & 5.708 & 5.681 & 5.606 \\
\hline AINV & 2.324 & 2.293 & 2.357 & $2.3(y)$ & 2.330 & 2.292 & 2.319 & 2.394 \\
\hline AIVI & 0.345 & 0.400 & 0.398 & 0.468 & 0,327 & 0.346 & 0.328 & 0.356 \\
\hline Ti & 0,650 & 0,675 & 0.626 & 0,634 & 0,696 & 0.661 & 0.727 & 0.649 \\
\hline Fe2 & 3.053 & 3.134 & 3.676 & 3.616 & 3.189 & 3.183 & 3.209 & 3.295 \\
\hline$C r$ & 0,000 & 0,004 & 0,012 & $0,(x) 0$ & 0.006 & 0.005 & 0,000 & 0.0015 \\
\hline Mn & 0.014 & 0.015 & 0.020 & $0,0) 7$ & 0,012 & 0.019 & 0,014 & 0.001 \\
\hline $\mathrm{MB}_{\mathrm{B}}$ & 2,3177 & 2,057 & 1,567 & 1,561 & $2(x) 3$ & 2.102 & 2,004 & 2.036 \\
\hline $\mathrm{Na}$ & 0.009 & 0.019 & 0,064 & 0.013 & 0.044 & 0.047 & $0.00(0)$ & 0.051 \\
\hline k & 1.923 & 1.946 & 2.028 & 1.962 & 1.960 & 1.930 & 1.964 & 1.989 \\
\hline $\mathrm{CF}$ & 0.375 & 0.583 & 0.367 & (0;:0172 & 0.267 & 0.173 & (1.) 286 & 0.321 \\
\hline $\mathrm{CCl}$ & 0.087 & 0.077 & 0.067 & (b.0.06 & 0.055 & 4.076 & f). 066 & 0,083 \\
\hline $\mathrm{Fe} /(\mathrm{Fe}+1$ & 0.569 & 0,604 & 0.701 & 6.698 & 0.6017 & 0,692 & 0,616 & 0.618 \\
\hline $\mathrm{Mq} / \mathrm{Mg}+$ & 0.431 & 0.396 & 0.299 & 0.312 & 0.393 & 0.398 & 0.384 & 0.382 \\
\hline
\end{tabular}

The subsolidus temperatures have been calculated for the pairs ilmenite-magnetite, using the software QUILF (Andersen et al. 1993), and plagioclase-alkali feldspar (Fuhrman \& Lindsley 1986). Results indicate temperatures around to $550^{\circ} \mathrm{C}$ and $630^{\circ} \mathrm{C}$, respectively. The higher temperature may indicate the feldspars re-equilibrium during the cooling of the magma, giving rise to replacement of plagioclase by alkali feldspar, as observed in thin section. The lower temperature may be due to the formation of the secondary magnetite.

$\operatorname{LogfO} \mathrm{O}_{2}$ values, obtained using the software QUILF through the ilmenite-magnetite pairs, are $-21.5 \pm 1.25 \mathrm{~atm}$, around $6 \log$ units below

Table 6 - Representative analyses ofilmenite and magnetite from the charnockltic rocks.

\begin{tabular}{|c|c|c|c|c|c|c|c|c|c|}
\hline Sumple & $\begin{array}{r}\mathrm{V} / \mathrm{a} \\
2 \times 1.1 \\
\end{array}$ & $\begin{array}{r}\mathrm{VA} \\
261.2 \\
1.2\end{array}$ & $\begin{array}{l}\mathrm{VA} \\
5 \mathbf{5 6} \\
\end{array}$ & $\begin{array}{l}V_{A} \\
257 \\
\end{array}$ & $\begin{array}{l}V_{A} \\
252 \\
\end{array}$ & $\begin{array}{r}V A \\
56.1 \\
\end{array}$ & $\begin{array}{r}V_{A} \\
56.2\end{array}$ & $\begin{array}{l}V_{A} \\
257 \\
\end{array}$ & $\begin{array}{l}V_{A} \\
252 \\
\end{array}$ \\
\hline Sid? & $\overline{0}$ & 0.04 & 011 & 0.09 & 0.19 & 0.19 & 0.25 & 0.10 & 0.21 \\
\hline & 43.73 & 43.53 & 45.04 & 45.76 & 45.95 & 0.12 & 0.29 & 0.05 & 0.33 \\
\hline A1203 & 0.09 & 0.13 & 0.06 & 0.07 & 0.07 & 0.36 & 1.05 & 0. 36 & 1.01 \\
\hline $\mathrm{Cr203}$ & 0.07 & 0.07 & 0.96 & 0.05 & 0.00 & 0.13 & 0.11 & 0.06 & 0.07 \\
\hline For & 49.55 & 48,99 & 46.57 & 45.13 & 44,50 & 90.86 & 90.72 & 90.07 & 89.07 \\
\hline $\mathrm{Mr}$ & 0.49 & 0.48 & 0.84 & 0.66 & 1.59 & 0.00 & 0.00 & 0.00 & 0.00 \\
\hline $\mathrm{MgO}$ & 0. & 0.57 & 0. & 0.37 & 0.17 & U. & 0.15 & 0.11 & 11 \\
\hline & 0.06 & 0.11 & 0.00 & 0,00 & 0.01 & 0.04 & 0.00 & 0.05 & 0.09 \\
\hline $\mathrm{CaO}$ & 0.06 & 0.03 & 0.06 & 0.04 & 0.07 & 0.08 & 0.00 & 0.60 & 0,00 \\
\hline $\mathrm{Na} 2 \mathrm{O}$ & 0.21 & 0.00 & 0.25 & 0 & 0.08 & 0.15 & 0.08 & 0.11 & 0.07 \\
\hline Tosat & 94.84 & 9395 & 9.3 .53 & 92.2 & 42.63 & 92,12 & 92.65 & 90,91 & 90.96 \\
\hline
\end{tabular}

\begin{tabular}{|c|c|c|c|c|c|c|c|c|c|}
\hline$\overline{A I}$ & $\overline{0.0} \mathrm{Fo}$ & & Sasec & $0 x$ & $\overline{002}$ & 0.017 & 0.048 & 0,017 & \\
\hline $\mathbf{T i}$ & 0.871 & 0.872 & 0.910 & 0.938 & 0.941 & 0.004 & 0.008 & 0.001 & 0.010 \\
\hline $\mathrm{Fc3}_{3}$ & 5 & 0.253 & 0.177 & 21 & 16 & 1.976 & 1.935 & 1.980 & 1.934 \\
\hline Fot & 0.841 & 0.838 & 0.870 & 0,9018 & 0.897 & 0.992 & 1.000 & 0.995 & 1.003 \\
\hline Mu & 0.011 & 0.011 & 0.019 & 0.015 & 0.037 & 0,000 & 0.000 & 0.000 & 0.000 \\
\hline$M x$ & 0,019 & 0,023 & 0.02 & 0.0 & 0.0 & 0.0 & 0,009 & & 0.006 \\
\hline tinger & 2.00 & 2,000 & 2.000 & 2.000 & 2.000 & 3.000 & 3,000 & 3.000 & 3.0 \\
\hline
\end{tabular}

\begin{tabular}{|c|c|c|c|c|c|c|c|c|c|}
\hline \multicolumn{10}{|c|}{ End members (\%) } \\
\hline${ }_{3}^{\mathrm{MgTiO}}$ & 1.9 & 2,3 & 2.2 & 1.5 & 0.7 & 0,70 & 0.60 & 0.46 & \\
\hline${ }_{3}^{\mathrm{MnT}}$ & 1.1 & 1.1 & 1.9 & 1.5 & 3.7 & 0 & 0 & 0 & 0 \\
\hline $\begin{array}{l}\text { FeTOO } \\
\mathrm{FezO3} \\
\mathrm{A2O3}\end{array}$ & $\begin{array}{r}84.1 \\
12.8 \\
0.1\end{array}$ & $\begin{array}{r}83.7 \\
12.7 \\
0.2\end{array}$ & $\begin{array}{r}86.9 \\
8.9 \\
0.1\end{array}$ & $\begin{array}{r}90.8 \\
6.1 \\
0.1\end{array}$ & $\begin{array}{r}89.7 \\
5.8 \\
0.1\end{array}$ & $\begin{array}{r}0.40 \\
0.40 \\
98.50\end{array}$ & $\begin{array}{r}2.60 \\
0.80 \\
0.00\end{array}$ & $\begin{array}{r}0.75 \\
0.10 \\
48.75\end{array}$ & $\begin{array}{r}2.73 \\
1.00 \\
05.87\end{array}$ \\
\hline
\end{tabular}

Table 4 - Representative analyses ofplagioclase, megacrysts and matrix grains, from the charnockltic rocks.
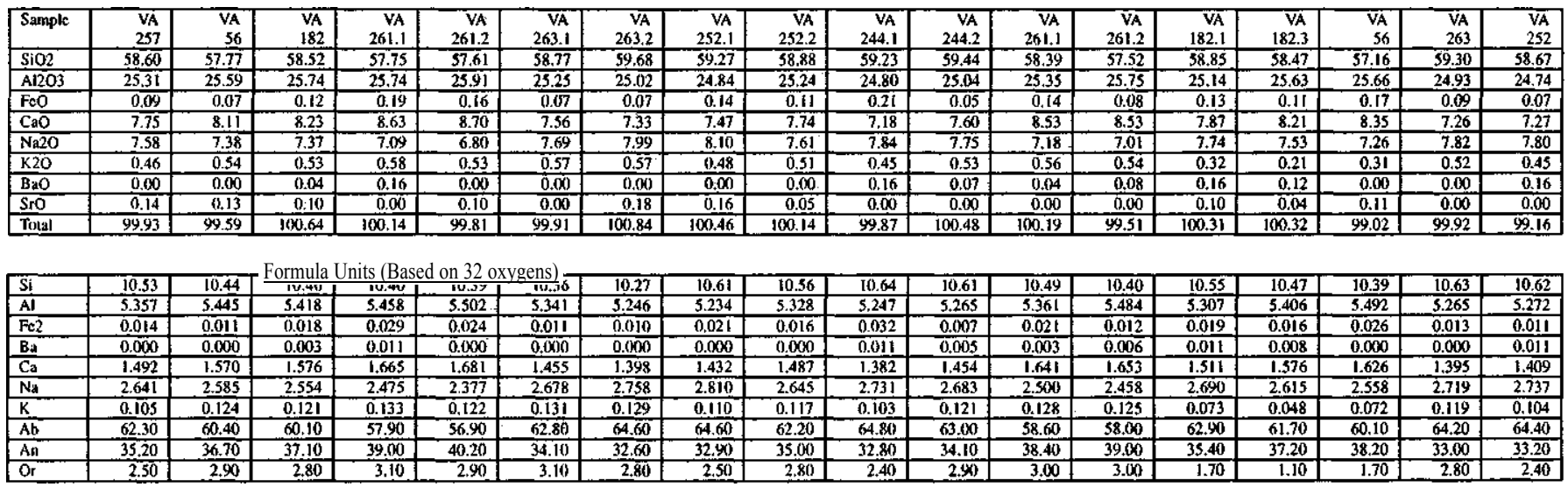

Table 5 - Representative analyses of alkali-feldspar, megacrysts and matrix grains, from the charnockltic rocks.

\begin{tabular}{|c|c|c|c|c|c|c|c|c|c|c|c|c|c|c|c|}
\hline Sample & $\begin{array}{r}V A \\
263.1 \\
\end{array}$ & $\begin{array}{r}V A \\
263.2 \\
\end{array}$ & $\begin{array}{r}V_{A} \\
257.1 \\
\end{array}$ & $\begin{array}{r}\text { VA } \\
257.2 \\
\end{array}$ & $\begin{array}{c}\text { VA } \\
56.1 \\
\end{array}$ & $\begin{array}{c}\mathrm{VA} \\
56.2 \\
\end{array}$ & $\begin{array}{r}V A \\
252.1 \\
\end{array}$ & $\begin{array}{r}\text { VA } \\
252.2 \\
\end{array}$ & $\begin{array}{l}\mathrm{VA} \\
\mathbf{2 4 4} \\
\end{array}$ & $\begin{array}{l}\overline{V A} \\
26 ! \\
\end{array}$ & $\begin{array}{r}\bar{V}_{A} \\
182.1 \\
\end{array}$ & $\begin{array}{r}V_{A} \\
182.2 \\
\end{array}$ & $\begin{array}{c}V_{A} \\
56 \\
\end{array}$ & $\begin{array}{c}V_{A} \\
257 \\
\end{array}$ & $\begin{array}{c}\mathrm{VA} \\
263 \\
\end{array}$ \\
\hline $\mathrm{SiO2}$ & 63.42 & 64.23 & 63.74 & 63.21 & 63.89 & 62.84 & 64.05 & 63.68 & 64.17 & 63.14 & 62.91 & 63.38 & 63.67 & 63.47 & 64.07 \\
\hline Al203 & 18.12 & 18.65 & 18.43 & 18.32 & 18.73 & 18,60 & 18.44 & 18,59 & 18,46 & 18.58 & 18.85 & 18.35 & 18.70 & $18.41)$ & 18.66 \\
\hline $\mathrm{FeO}$ & 0.07 & 0.00 & 0.11 & 0.09 & 0.08 & 0.08 & 0.03 & (0.(X) & 0.63 & 6.09 & 0.10 & (0).00 & 0,08 & 005 & 0.92 \\
\hline $\mathrm{Na} 2 \mathrm{O}$ & 1.21 & 2.80 & 1.31 & 1.52 & 1.29 & 1.45 & 2.19 & 1.43 & 2.49 & (1)(C) & 0.00 & 0,00 & 0.00 & $0,00)$ & 0.07 \\
\hline $\mathrm{K} 20$ & 15.34 & 13.27 & 14.80 & 14,48 & 14.28 & 14.58 & 13.70 & 15.00 & 13.38 & 1.33 & 1.20 & 1.45 & 1.37 & 2.29 & 3.57 \\
\hline $\mathrm{BaO}$ & 1.06 & 1.01 & 1.54 & 1.63 & 2.33 & 2.13 & 1.36 & 1.33 & 0.94 & 14.79 & 15,08 & 14.76 & 14.46 & 13.70 & 11.87 \\
\hline Sro & 1).00 & 0.04 & 0.06 & 0.11 & 0.62 & 0.04 & 0.00 & 0.17 & 0.03 & 2.05 & 1.75 & 1.97 & 2.19 & 1.36 & 0.62 \\
\hline Folal & 99.22 & 100,00 & 99.99 & 99.36 & 100.62 & 99.72 & 99.77 & 100.20 & 99.50 & 0.00 & 0.00 & (1).05. & (1).14 & 0.13 & 0,08 \\
\hline & & & & & & & & & & 99.98 & 99.89 & 99.96 & $100.6]$ & 99.40 & 99.86 \\
\hline
\end{tabular}

Formula Units (based on 22 oxygens)

\begin{tabular}{|c|c|c|c|c|c|c|c|c|c|c|c|c|c|c|c|}
\hline$\overline{\mathrm{Si}}$ & 11.92 & 11.88 & 11.89 & 11.88 & 11.87 & 11.82 & 11.91 & 11.86 & 11.91 & 11.83 & 11.79 & 11.87 & 11.85 & 11.87 & 11.83 \\
\hline Al & $4.11 \times 9$ & V 4062 & 4.050 & 4.0154 & 4,098 & 4.118 & 4.037 & $4.07 \%$ & 4.037 & 4.101 & 4.161 & 4,048 & 4.1198 & 4,053 & 4,058 \\
\hline $\mathrm{Fe} 2$ & 0.011 & 0.0000 & $(0,0177$ & (1).(1)14 & 0.012 & 0.013 & 0.005 & 0.060 & nocos & 0.014 & 0.016 & 0.000 & 0.012 & 0.008 & 0.142 \\
\hline $\mathrm{Ba}$ & 0.078 & 0.073 & (1).113 & 0.120 & 0.170 & 0.157 & 0.094 & (.).97 & 0.068 & 0.151 & 0.129 & 0.145 & 0.160 & 0.100 & 0.045 \\
\hline $\mathrm{Na}$ & 0.441 & 1.004 & 0.474 & 0.554 & 0.465 & 0.529 & 0.784 & 0.516 & 0.896 & 0.000 & 0.000 & $0.0 \times 0$ & 0.000 & 0.000 & 0.014 \\
\hline$k$ & 3.677 & 3.131 & 3.523 & 3.471 & 3.384 & 3.497 & 3.249 & 3.564 & 3.169 & 0.483 & 0.436 & 0.527 & 0.494 & 0.831 & 1.278 \\
\hline $\mathbf{A b}$ & 10.70 & 24.30 & 11.90 & 13.80 & 12.10 & 13.10 & 19.50 & 12.60 & 22.00 & 3.536 & 3.606 & 3.527 & 3.433 & 3.269 & 2.796 \\
\hline An & 0.00 & $0.0 x$ & $n, \infty)$ & 0.00 & 0.00 & 0.60 & $0,0 \%$ & 0.00 & 0.60 & $12 .(0)$ & 10.80 & 13.00 & 12.60 & 20.30 & 31.30 \\
\hline$\phi r$ & 89.30 & 75,70 & 88.10 & 86.20 & 87.90 & 86.90 & 80.50 & 87.40 & 78.00 & $(0,000$ & 0.000 & $0.0 \times 0$ & 0.000 & 0.000 & 0.300 \\
\hline & & & & & & & & & & 88.00 & 89.20 & 87,60 & 87.40 & 79.70 & 68.40 \\
\hline
\end{tabular}


the values calculated using the FMQ buffer at the same P-T conditions. This confirms the highly reducing conditions of these rocks, as already discussed above, which is also emphasized by the low $\mathrm{X}_{\mathrm{Mg}}$ of whole rocks and mafic minerals.

Estimates of the crystallization pressure of the charnockitic rocks using the Al-contents in hornblende provided the values shown in Table 7. In spite of the restrictions for the use of the geobarometer (Hammarstrom \& Zen 1986, Hollister et al. 1987, Schmidt 1992), the obtained results, ranging from 6 to $7 \mathrm{kbar}$, are compatible with the pressure of the regional metamorphism, 8 to $9 \mathrm{~kb}$ (Seindensticker \& Wiedemann 1993).

High amounts of perthitic feldspar/mesoperthite may suggest an initial hypersolvus system for the charnockitic rocks from Várzea Alegre. However, the large amount of modal plagioclase, normative anorthite (up to 25\%), and the composition of the plagioclase (intermediate andesine) do not fit very well with such hypothesis.

The general conditions for the evolution of the Va"rzea Alegre charnockitic rocks can be summarized as the following: (a) a primary paragenesis (orthopyroxene, alkali-feldspar, plagioclase, ilmenite, quartz, and biotite(?), plus accessory phases) crystallized at high temperatures and moderate to high pressures in a strongly reducing environment; b) the main magmatic processes involved fractional crystallization and to a lesser extent, magma mixing, providing mantle
Table 7 - Barometric determinations using Al-contents in amphibole. H\&Z: Hammarstrom \& Zen (1986), Holl. et al: Hollister et al (1987), Schmidt: Schmidt (1992).

\begin{tabular}{|c|c|c|c|}
\hline Sample & H\&Z & Holl. et al. & Schmidt \\
\hline VA-257.1 & $6.1 \pm 3 \mathrm{~kb}$ & $6.5 \pm 1 \mathrm{~kb}$ & $6.5 \pm 0.6 \mathrm{~kb}$ \\
VA-257.2 & $6.2 \pm 3 \mathrm{~kb}$ & $6.6 \pm 1 \mathrm{~kb}$ & $6.6 \pm 0.6 \mathrm{~kb}$ \\
VA-182.1 & $6.3 \pm 3 \mathrm{~kb}$ & $6.7 \pm 1 \mathrm{~kb}$ & $6.6 \pm 0.6 \mathrm{~kb}$ \\
VA-182.2 & $5.7 \pm 3 \mathrm{~kb}$ & $6.0 \pm 1 \mathrm{~kb}$ & $6.1 \pm 0.6 \mathrm{~kb}$ \\
VA-261.1 & $6.4 \pm 3 \mathrm{~kb}$ & $6.8 \pm 1 \mathrm{~kb}$ & $6.7 \pm 0.6 \mathrm{~kb}$ \\
\hline
\end{tabular}

plus crustal chemical signature for the rocks; c) subsolidus reactions, due to hydration of the system, occurred at lower temperatures. They led to replacement of orthopyroxene, plagioclase, and ilmenite, generating lower temperature phases, and exsolution in orthopyroxene and alkali-feldspar.

Acknowledgements The authors are grateful to $\mathrm{CNPq}$ and PADCT/FINEP program for the financial support to this research project. Two anonymous reviewers collaborated to the improving the manuscript.

\section{References}

Alien, P.; Condic, K.; Narayana, B.L. 1985. The geochemistry of prograde and retrograde charnockite gneiss reaction in southern India. Geoch. Cosmoch. Acta, 49: 326-336.

Andersen, D.; Lindsley, D.H.; Davidson, P.M. 1993. QUILF: A PASCAL program to assess equilibria among Fe-Mg-Ti oxides, pyroxenes, olivine and quart/.. Com/.. Geosci., 19 (9): $1333-1350$.

Barbey, P. \& Cuncy, M. 1982. K, Rb, Sr, U and Th geochemistry of the Lapland granulitcs (Fennoscandia). LILE fractionalion controlling factors. Contrib. Mineral. Petrol., 81: 304-316.

Barbosa, J.S.F. 1990. The granulitcs of the Jequité Complex and Atlantic coast mobile bell, Southern Bahia - An expression of Archcan/Early Protcrozoic plate convergence. In: D. Vielzeuf \& Ph. -VidaI (eds.) Granulites anil Crustal Evolution. Kluwcr Academic Publishers, p. 195-221.

Basci, M.A.S.; Siga Jr., O.; Machiavclli, A.; Mancini, F. 1992. Evolução tectônica dos tcrrenos entre os Cinturoes Ribeira e Dom Feliciano. Rev. Bras. Geo., 22 (2): 216-221

Bayer, P.; Horn, H.; Lammerer.B.; Schmidt-Thomd, R.; Weber-Diefenbach,K.; Wiedemann, C.M. 1986. The Brasiliano Mobile Bell in Southern Espfrilo Sanlo (Brax.il) and Its Igneous Intrusions. Zhl.Geol.Paleont., 1,9/10: 1429-1439.

Campos Neto, M.C. \& Figueiredo, M.C.H. 1990. Evolução.Sociológica dos terrenos Costciro, Parafba do Sul e Juiz de Fora (RJ-MG-ES). In: SBG, Congr. Bras. Geol., 36, Natal, Anais, 6:2631-2648.

Campos Neto, M.C.; Figueiredo, M.C.H.; Janasi, V.A.; Basci, M.A.S.; Freyer, B.J. 1988. The S5o Jos6 do Rio Pardo mangerilie-granilic suite, southeastern Brazil. Geoch. Brazil., 2: $185-189$

Condie, K.C.; Alien, P. \& Narayama, B.L. 1982. Geochemistry of the Archcan low-to high grade transition zone, southern India. Contrib. Mineral. Petrol., 81: 157-167.

Deer, W.A.; Howie, R.A.; Zussman, J. 1966. An introduction to the rock forming minerals. Longman, Green and Co., Ltd. London. 558 p.

Drury, S. A. 1973. The geochemistry of Precambrian granulitcs facics rocks from the Lewisian complex of Tircc, Inner Hebrides, Scotland. Chem. Geol, 11: 167-188;

Field, D.; Drury, S.A.; Cooper, D.C. 1980. Rare-earth and LILelement fractionation in high-grade charnockitic gneisses, south Norway. Lithox, 13: 281-289.

Figueiredo, M. C. H. 1982. Geochemistry of high-grade complexes of Bahia Stale, Brazil. Rev. Bras. Geoc.., $12(1,2,3): 307-312$

Fritzer, T. 1991. Das Guac,uf Lineament und die orogenc Enlwicklung des Zenlralcn Ribeira Bell (Espírilo Sanlo, Brasilien). Miinch. Hef.. 2, 196p.

Fuhrman \& Lindsley, 1986

Gasparini, P. \& Manlovani, M.S.M. 1979. Geochemistry of charnockitcs from São Paulo Stale, Brazil. Earth Planet. Sc. Utters, 42: 311-320.

Harmmartrom, J.M. \& Zen, E-an 1986. Aluminium in hornblende: an empirical igneous geobaromcler. Am. Mineral., 71:1297-1313.

Hewiii, D.A. \& Woncs, D.R. 1984. Experimental phase relations of ihe micas. In: S.W. Bailey (ed.), Micas. Mineral. Soc. Amer., Reviews in Mineralogy, 13: 201-297.

Hollister, L.S.; Grisson, G.C.; Peters, E.K.; Slowell, H.H.; Sisson, V.B. 1987. Confirmalion of Ihe empirical calibralion of $\mathrm{Al}$ in hornblende wilh pressure of solidification of calc-alkaline plulons. Amer. Mineral., 72: 231-239.

Hubbard, F.H. \& Whilley, J.E. 1979. REE in charnockile and associated rocks, southwesl Sweden. Lithos, $12: 1-11$.

lyer, S.S; Cchouduri, A.; Pallison, D.R.M.; DC Paoli, G.R. 1996. Petrology and geochemisiry of the Neoproterozoic Guaxupd granulitc facics terrain, southeastern Brazil. Precamh. Res., 77: $23-40$.

Janasi, V.A. 1992. Rochas sienlticas e mangeritico-charnoquiiticas neoproterozóicas da região entre Caldas e Campestre (MG): aspectos petrológicos. Institute of Geosciences, Universily of São Paulo, São Paulo, Doctoral Dissert., 298p.

Jordt-Evangclisla, H. 1996. Igneous charnockilcs in The southeastern iransition/one between the São Francisco craton and ihc Costciro mobile belt, Brazil. Rev. Bras. Geoc., 26 (2): 93-102.

Kaiyi, W.; Yuchua, Y.; Ruiying, V.; Yifci, C. 1985. REE gcochemislry of early Precambrian charnockilcs and lonalitic-granodiorilic gneisses of ihc Qianan region, casicrn Hcbci, north China. Precamh. Res., 27: 63-84.

Lammerer, B. 1987. Short notes in a struclural scclion through ihc Ribcira Mobile Bell (Minas Gerais and Espírito Santo, Brazil). Zbl. Geol. Paiaont., Toil I (7/8): 719-728.

Leake, B., 1978. Nomenclature of amphiboles. Mineral. Mag., 42: 533-563.

Mason, G.H. 1985. The mineralogy and textures of the coastal balholilh, Peru. In: The Peruvian Andes. John Wiley \& Sons, New York, 328p.
Marlignolc, J. 1979. Charnockile genesis and ihc Prolerozoic crusl. Precamb. Res., 9: 303-310.

Mcdciros, S. R. 1993. Geologia, petrologia e geoquímica do Complexo Intrusivo de Várzea Alegre, ES. Institute of Geosciênces, UFRJ, Rio de Janeiro, Master Sc. Dissert., 143p.

Mcdciros, S.R.; Mendes, J.C.; Wiedemann, C.M. 1994. Fcic,5cs diagnósticas do complexo intrusivo de Várzea Alegre, ES. In: SBG, Congr. Bras. Geol., 38 Balncário Camboriú, Anais, $1: 140-141$

Mcndcs, J.C.; McRcalh, I.; Wiedemann, C.M.; Figueiredo, M.C.H. 1997. Chatnoquilóides do Macico de Varzea Alegre: um novo exemplo do magmalistno cálcio-alcalino de alto K no arco magmático do Espírito Sanlo. Rev. Bras. Geoc., 27 (1):13-24.

Nancy, M.T. 1983. Phase equilibria of rock-forming fcrromagncsian silicates in granilic syslems. Amer. Jour. Sci., 283: 993-1033.

Olivcira, M.A.F. 1984 Considerações sobre a evolução geoldgica do Complexo Varginha. In: SBG, Cong. Bras. Geol., 33, Rio de Janeiro, Anais, 5: 2302-2304.

Ormaascn, D.E. 1977. Pelrology of ihe Hopen mangerilc-charnockile intrusion, Lofolen, north Norway. Lithos, 10: 291 -310.

Pelersen, J.S. 1980. Rarc-carlh elemeni fractionalion and petrogenelic modelling in charnockilic rocks, southwest Norway. Contrib. Mineral. Petrol., 73: 161-172.

Rego, I. T.S.F. 1989. Petrologia e geoquímica da unidade chamoquitica Beta Joana, São Fidelis, $R J$. Institute of Geosciênces, USP, São Paulo, Doctoral Dissert., 348p.

Richard, L. L. 1995. MINPET Geological Software - mincralogical and peirological dala processing syslcm.

Saxcna, S.K. 1968. Chemical sludy of phase equilibria in charnockitcs, Varberg, Swcedcn. Amer Mineral., 53: 1674-1695.

Schmidt, M.W. 1992. Amphibole composition in lonalile as a funclion of pressure: an experimenlal calibralion of the Al-in-hornblendc barometer. Contrib. Mineral. Petrol., 110:304-310.

Scidenslickcr, U. \& Wiedemann, C. 1993. Geochcmisiry and origin of lower crusl granulilc facies rocks in the Serra do Capara6 region, Esp.Santo/Minas Gcrais, Brazil. 7. South Am. Earth Sc., 6 (4): 289-298.

Siga JR., O.; Teixcira, W.; Cordani, U. G.; Kawashila, K.; Delhal, J. 1982. O padrão geológico-geocronológico das rochas dc alto grau da pane setentrional da Faixa Ribeira, a none do Rio de Janeiro, Brasil. In: Cong. Lalinoamericano dc Geologia, V, Argentina. Adas, I: $349-370$

Sluilncr, Z. \& Weber-Diefenbach, K. 1989. Geochcmisiry of Charnocnderbilic Granulites and Associated Amphibolitic Gneisses in Ihc Coasl Region of Espírito Santo, Brazil. Zbl. Geol. Paiaont. Tcil I, H. 5/6: 917-931.

Siillncr, F.; Lammerer, B.; Weber-Dicfenbach, K. 1991. Die Kruslenenlwicklung in dcr Kiisicnrcgion nordlich von Rio de Janciro/Brasilien. Miinchner Geologische Hefte, 4, 100 .

Tarncy, J. \& Weaver, B. L. 1987. Geochemistry of the Scourian complex: peirogenesis and tectonic models. In: R. G. Park \& J. Tarncy (cds). Evolution of the Lewisian and comparable Precambrian high grade terrains. Geological Society Special Publications, 27: 45-56.

Watson, E.B. \& Harrison, T.M. 1983. Zircon saturation revisited: tcmpcralurc and composiiion cffccls in a varicly of cruslal magma lypcs. Earth Planet. Sci. Letters, 64: 295-304.

Walson, E.B. \& Harrison, T.M. 1984. Accessory minerals and the geochemical evolulion of cruslal magmalic syslems: a summary and prospectus of experimental approaches. Physics Earth Planet. Inter., 35: 19-30.

Wcndlanl, R.F. 1981. Influence of $\mathrm{CO}_{2}$ on melting of model granulitc facies assemblages: a model for ihc genesis of charnockites. Amer. Mineral., 66: 1164-1174.

Wiedemann, C. 1993. The evolulion of the Early Paleozoic, late- lo post-collisional magmalic arc of ihc coastal mobile bell in the stale of Espírilo Sanlo, Eastern Brazil. An. Acad. bras.Ci.., 65(1): 163-181.

Wiedemann, C.; Baycr, P.; Horn, H.; Lammerer; B.; Ludka, I.P.; Schmidt-Thomc, R.; Wcbcr-Dicfcnbach, K. 1986. Macic.os inlrusivos do Espírito Sanlo c scu contexto regional. Rev. Bras. Geoc., 16(1): 24-37.

Wiedemann, C.M.; Medciros, S.R.; Mendes, J.C. 1994. Divcrsidade geoquímica do polidiapirismo lardi-Brasíliano no Cinturão Movel Attântico. Excmplo do complexo inlrusivo dc Várzea Alegre - ES. In: SBG, Congr. Bras. Geol., 38, BalncaYio Camboriu, Bolclim de resumos expandidos, 1: 129-131. 